\title{
Thermotalea metallivorans gen. nov., sp. nov., a thermophilic, anaerobic bacterium from the Great Artesian Basin of Australia aquifer
}

Correspondence Bharat K. C. Patel b.patel@griffith.edu.au

\author{
Christopher D. Ogg and Bharat K. C. Patel
}

Microbial Gene Research and Resources Facility, School of Biomolecular and Physical Sciences, Griffith University, Brisbane, OLD 4111, Australia

\begin{abstract}
A strictly anaerobic, thermophilic bacterium, designated strain $\mathrm{B} 2-1^{\top}$, was isolated from microbial mats colonizing a runoff channel formed by free-flowing thermal water from a Great Artesian Basin, Australia, bore well (registered number 17263). The cells of strain B2-1 ${ }^{\top}$ were slightly curved rods $(3.0-3.5 \times 0.6-0.7 \mu \mathrm{m})$ which stained Gram-negative. The strain grew optimally in tryptone-yeast extract-glucose medium at $50{ }^{\circ} \mathrm{C}$ (temperature growth range $30-55^{\circ} \mathrm{C}$ ) and a pH of 8 ( $\mathrm{pH}$ growth range $6.5-9)$. Strain $\mathrm{B} 2-^{\top}{ }^{\top}$ grew poorly on yeast extract $(0.2 \%)$ and/or tryptone $(0.2 \%)$, which were obligately required for growth on other energy sources, including a range of other carbohydrates and organic acids, but not amino acids. The end-products of glucose fermentation were ethanol and acetate. In the presence of $0.2 \%$ yeast extract, iron(III), manganese(IV) and elemental sulfur were reduced but sulfate, thiosulfate, sulfite, nitrate and nitrite were not reduced. Growth was inhibited by chloramphenicol, streptomycin, tetracycline, penicillin, ampicillin, sodium azide and by $\mathrm{NaCl}$ concentrations greater than $4 \%(\mathrm{w} / \mathrm{v})$. The DNA $\mathrm{G}+\mathrm{C}$ content was $48 \pm 1 \mathrm{~mol} \%$ as determined by the thermal denaturation method. 16S rRNA gene sequence analysis indicated that strain $\mathrm{B} 2-1^{\top}$ was a member of the family Clostridiaceae, class Clostridia, phylum Firmicutes and was most closely related to Geosporobacter subterraneus DSM $17957^{\top}$ (89.9\% similarity). On the basis of $16 \mathrm{~S}$ rRNA gene sequence comparisons and physiological characteristics, strain $B 2-1^{\top}$ is considered to represent a novel species of a new genus, for which the name Thermotalea metallivorans gen. nov., sp. nov. is proposed. The type strain is $B 2-1^{\top}\left(=\right.$ KCTC $5625^{\top}=J C M 15105^{\top}=$ DSM $\left.21119^{\top}\right)$.
\end{abstract}

The Great Artesian Basin (GAB) underlies approximately $22 \%$ of the arid and subarid regions of the Australian continent, an area of over $1.7 \times 10^{6} \mathrm{~km}^{2}$, with a water storage capacity of $8.7 \times 10^{12} \mathrm{~m}^{3}$, and is considered to be the world's largest geothermal subsurface aquifer (Habermahl, 1980). The GAB was formed between 100 and 250 million years ago and contains groundwaters which are estimated to be 2 million years old. It is composed of alternating layers of water-bearing permeable sandstone aquifers and non-water-bearing impermeable shale and includes two regions that contain the largest onshore oil and gas reserves in Australia. These geological formations have an immense influence on the chemical composition of GAB groundwaters, which can be bicarbonate-, chloride-, sulfate- or iron-rich. The GAB subsurface waters flow from the recharge areas at the edge of the basin to the discharge areas in central Australia as mound

Abbreviations: GAB, Great Artesian Basin; TYEG, tryptone-yeast extract-glucose medium.

The GenBank/EMBL/DDBJ accession number for the $16 \mathrm{~S}$ rRNA gene sequence of strain $B 2-1^{\top}$ is EU443727. springs at an estimated rate of $1-5 \mathrm{~m} \mathrm{year}^{-1}$ and are heated by the Earth's magma due to the aquifer's great depth. The GAB is tapped by more than 5000 free-flowing bores which provide vital water to outback communities where it is used for agricultural, industrial and domestic purposes. These bores can be found up to $3000 \mathrm{~m}$ deep, with source temperatures ranging from 30 to $100{ }^{\circ} \mathrm{C}$ depending on the bore depth.

The unique chemical composition, combined with varying temperatures and the slow flow rate of GAB groundwaters, provides a conducive environment for the growth of a wide diversity of microbial life. Distinct thriving macroscopic microbial mat communities can be seen colonizing specific temperatures along the temperature gradient of runoff channels formed by the free-flowing bores. Cultureindependent analyses of four microbial mat communities existing in the New Lorne bore (registered bore number 17263) have indicated that members of the genus Thermus dominated the $75{ }^{\circ} \mathrm{C}$ grey mat, members of the genus Meiothermus dominated the $66{ }^{\circ} \mathrm{C}$ red mat, Cyanobacteria dominated the $57{ }^{\circ} \mathrm{C}$ green mat and members of the Deinococcus-Thermus group and class Alphaproteobacteria 
dominate the $52{ }^{\circ} \mathrm{C}$ brown mat (Spanevello, 2001). Identical phylotypes were discovered in adjacent communities and the phylogenetic diversity was found to increase as the water temperature decreased. Furthermore, species spanning the full diversity of the domain Bacteria were identified, including a diverse range of as-yetuncultured, novel organisms.

Numerous thermophilic and mesophilic micro-organisms have been characterized from the GAB waters and they include sulfate-reducers (Love et al., 1993; Redburn \& Patel, 1994), carbohydrate-fermenters (Andrews \& Patel, 1996), strict aerobes (Kanso \& Patel, 2003; Spanevello et al., 2002) and metal-reducers (Kanso et al., 2002). Metalreducing micro-organisms are known to have a significant impact on the geochemistry of deep subsurface aquifers through their cycling of metals [particularly $\mathrm{Fe}(\mathrm{III})$ and $\mathrm{Mn}(\mathrm{IV})]$ and organic matter, and thereby have an influence on water quality and taste (Lovley, 1997). Our findings of metal-reducers (Kanso et al., 2002) in the GAB environment has led to a concern that their colonization of, and growth on, the metal casing of bores could lead to corrosion, causing significant water leakage and therefore economic loss and hardship to the communities that rely on the aquifer waters.

In this report, we describe a novel, strictly anaerobic, thermophilic, metal-reducing micro-organism, designated strain $\mathrm{B} 2-1^{\mathrm{T}}$, inhabiting the $52{ }^{\circ} \mathrm{C}$ brown microbial mat of a GAB bore runoff channel. The microbial mat sample used in this study was collected from the runoff channel of the New Lorne Bore situated near Blackall, some $1000 \mathrm{~km}$ north-west of Brisbane, QLD, Australia ( $24^{\circ} 54^{\prime} 48^{\prime \prime} \mathrm{S}$ $\left.145^{\circ} 08^{\prime} 18^{\prime \prime} \mathrm{E}\right)$. The bore was drilled in 1966 and is $1613 \mathrm{~m}$ deep. The temperature of the free-flowing water at the bore head was $88{ }^{\circ} \mathrm{C}$, with a $\mathrm{pH}$ of 8.5 and a flow rate of $7.61 \mathrm{l} \mathrm{s}^{-1}$ at the time of sampling. The iron and manganese concentrations of the free-flowing water were found to be $0.01 \mathrm{mg} \mathrm{l}^{-1}$. The brown coloured microbial mats that thrived at $52{ }^{\circ} \mathrm{C}$ were collected in sterile glass vessels. The vessels were filled to the brim with water from the runoff channel, capped, transported to the laboratory and stored at $4{ }^{\circ} \mathrm{C}$ until required. The microbial mats have been described by Spanevello et al. (2002).

Enrichment and isolation were performed in anaerobic PL medium. PL medium contained $\left(\mathrm{l}^{-1}\right.$ deionized water): $1 \mathrm{~g}$ $\mathrm{NH}_{4} \mathrm{Cl}, 0.6 \mathrm{~g} \mathrm{~K}_{2} \mathrm{HPO}_{4}, 0.3 \mathrm{~g} \mathrm{KH}_{2} \mathrm{PO}_{4}, 0.1 \mathrm{~g} \mathrm{MgCl}_{2} .6 \mathrm{H}_{2} \mathrm{O}$, $0.1 \mathrm{~g} \mathrm{CaCl}_{2} \cdot 2 \mathrm{H}_{2} \mathrm{O}, 1.0 \mathrm{~g} \mathrm{NaCl}, 1 \mathrm{ml}$ vitamin solution (Wolin et al., 1963), $1 \mathrm{ml}$ trace-element solution (Zeikus et al., 1979), $12.0 \mathrm{~g}$ HEPES, $2.0 \mathrm{~g}$ yeast extract and $2.0 \mathrm{~g}$ ammonium $\mathrm{Fe}$ (III) citrate (brown). The $\mathrm{pH}$ of the medium was adjusted to 7.2 with $1 \mathrm{M} \mathrm{NaOH}$ and $1 \mathrm{M} \mathrm{HCl}$ and heated for $10 \mathrm{~min}$ in an autoclave at $121^{\circ} \mathrm{C}$ and under 1$1.5 \mathrm{~kg} \mathrm{~cm}^{-2}$ pressure. The medium was subsequently cooled under a stream of oxygen-free nitrogen gas, dispensed into Hungate tubes under oxygen-free nitrogen gas and sterilized for $30 \mathrm{~min}$ at $121{ }^{\circ} \mathrm{C}$ and $1-1.5 \mathrm{~kg} \mathrm{~cm}^{-2}$ pressure. Enrichment cultures were initiated by injecting
$500 \mu \mathrm{l}$ mat sample suspension into PL medium $(9.5 \mathrm{ml})$ followed by incubation at $50{ }^{\circ} \mathrm{C}$ for 2 days. The enrichment culture was serially diluted, incubated under the same conditions and the tube containing the lowest serial dilution was selected. This procedure was repeated at least three times before a strain, designated $\mathrm{B} 2-\mathrm{1}^{\mathrm{T}}$, was isolated and deemed to be a pure culture. The strain's purity was subsequently confirmed by $16 \mathrm{~S}$ rRNA gene sequencing and the pure culture was stored in a glycerol-PL medium (50:50) mixture at $-20{ }^{\circ} \mathrm{C}$.

Cell morphology was determined by phase-contrast light microscopy and by electron microscopy (Kanso \& Patel, 2003). The cells of strain $\mathrm{B} 2-1^{\mathrm{T}}$ were peritrichously flagellated, slightly curved rods $(3.0-3.5 \times 0.6-0.7 \mu \mathrm{m})$ and existed singly and rarely in long chains. Spores were not observed under the microscope from cultures that had been grown under suboptimal conditions $(\mathrm{pH}$ and temperatures), after storage at $4{ }^{\circ} \mathrm{C}$ for 5 days or with substrates that included glucose and xylose. In addition, cultures heat-treated at $95{ }^{\circ} \mathrm{C}$ for $10 \mathrm{~min}$ did not grow after subculture into tryptone-yeast extract-glucose (TYEG) medium, suggesting the absence of heat-resistant bodies such as spores. Cells of strain B2- $1^{\mathrm{T}}$ stained Gram-negative and electron micrographs of thin sections confirmed a Gram-negative cell-wall ultrastructure consisting of an inner electron-dense layer adjacent to the cell membrane and an outer electron-light layer consisting of regular protein subunits (Fig. 1).

Unless otherwise indicated, all growth experiments were conducted at least twice and cultures were subcultured at least once in the same medium prior to the performance of the experiment. The growth of strain $\mathrm{B} 2-1^{\mathrm{T}}$ was tested in anaerobic TYEG medium which consisted of low phosphate buffered salts (LPBS) amended with $0.2 \%$ each of tryptone, yeast extract and glucose at temperatures ranging from 26 to $70{ }^{\circ} \mathrm{C}$ and at $\mathrm{pH}$ values ranging from 5.0 to 9.5 . Anaerobic TYEG medium was prepared as described previously (Patel et al., 1985a, b). Growth was measured at $580 \mathrm{~nm}$ by inserting Hungate tubes directly into a modified cuvette holder of a Novaspec LKB spectrophotometer (Pharmacia-Biotech Pty. Ltd). Strain B2-1 ${ }^{\mathrm{T}}$ grew optimally in TYEG medium at $50{ }^{\circ} \mathrm{C}$ (temperature growth range, $30-55{ }^{\circ} \mathrm{C}$ ) and a $\mathrm{pH}$ of $8(\mathrm{pH}$ growth range, 6-9) with a generation time of $6.7 \mathrm{~h}$. Unless indicated otherwise, all subsequent growth experiments were conducted using these conditions.

Strain $\mathrm{B} 2-1^{\mathrm{T}}$ was tested for its ability to grow in LPBS amended with $0.2 \%$ tryptone (medium $\mathrm{T}$ ), $0.2 \%$ yeast extract (medium YE) or $0.2 \%$ each of tryptone and yeast extract (medium TYE) as carbon sources. Compared with growth of the novel strain in TYEG medium (an $\mathrm{OD}_{580}$ $0.3=100 \%$ ), growth of approximately $28 \%, 20 \%$ and $40 \%$ was obtained in LPBS, YE and TYE, respectively. No growth of strain $\mathrm{B} 2-1^{\mathrm{T}}$ was observed with $0.2 \%$ glucose (medium G) as the sole carbon source, but glucose $(0.2 \%)$ was fermented in the presence of $0.2 \%$ yeast extract (YEG 


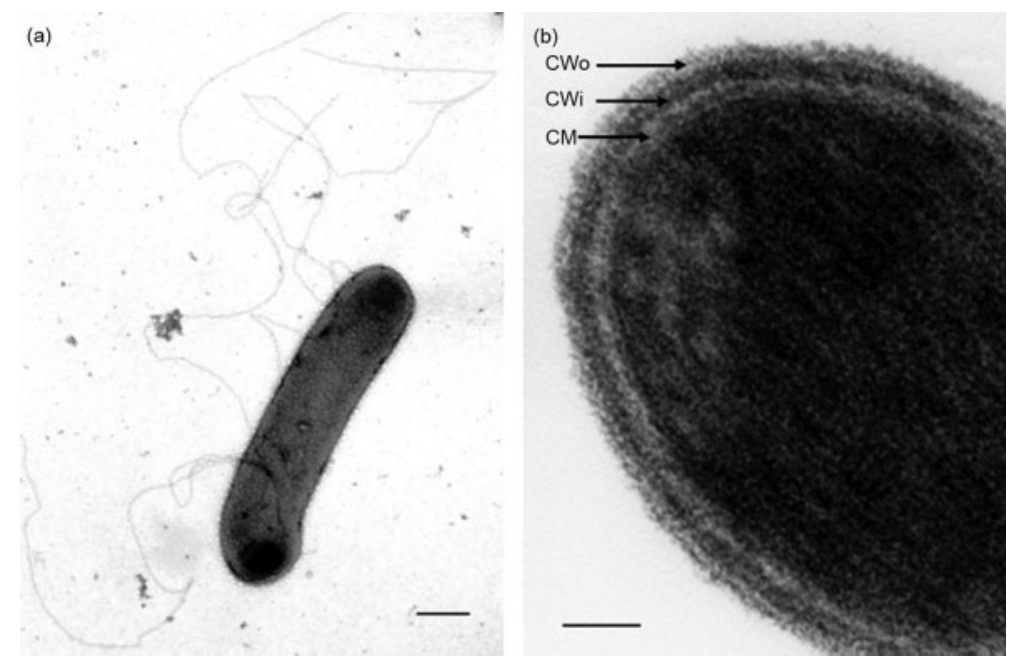

Fig. 1. Electron micrographs of cells of strain $B 2-1^{\top}$. (a) Negatively stained cells showing a peritrichously flagellated cell. Bar, $500 \mathrm{~nm}$. (b) Transmission electron micrograph of a thin section showing cell-wall ultrastructure revealing the presence of a cytoplasmic membrane (CM), an electron-dense wall layer adjacent to the membrane (CWi) and an electron-light outer cell-wall layer composed of regular subunits (CWo). Bar, $50 \mathrm{~nm}$.

medium) and $0.2 \%$ tryptone (TG medium) reaching approximately $75 \%$ and equal maximum growth, respectively compared with the maximum growth in TYEG medium. No growth of strain $\mathrm{B} 2-1^{\mathrm{T}}$ was observed when yeast extract concentrations in the YEG medium were lowered to $0.005 \%$ or $0.01 \%$ and approximately $65 \%$ growth was observed with $0.1 \%$ yeast extract compared with growth in $0.2 \%$ yeast extract. This indicates that components in yeast extract were required for glucose fermentation in a dose-dependent manner.

Substrate utilization tests were performed in the presence of $0.2 \%$ yeast extract. Soluble substrates were added to sterile YE medium from sterile anaerobic stock solutions to a final concentration of $0.2 \%$. Insoluble substrates were weighed directly into Hungate tubes, YE medium was dispensed and the medium was sterilized. Growth was measured three times a day at $580 \mathrm{~nm}$ until the stationary phase was reached. Growth was taken as positive if the turbidity of the culture was at least $20 \%$ higher in YE medium containing substrates when compared to YE medium lacking the substrates. Growth was observed with glucose, sucrose, maltose, fructose, arabinose, mannose, cellobiose, myo-inositol, mannitol, Casamino acids, serine and leucine but not with lactose, galactose, raffinose, xylose, ribose, chitin, starch, amylopectin, casein, xylan, acetate, propionate, lactate, formate, pyruvate, ethanol, glycerol, amyl media, arginine, alanine, glycine, threonine, glutamate, isoleucine or methionine.

The metabolic profile of strain $\mathrm{B} 2-1^{\mathrm{T}}$ was further investigated using GP2 Biolog MicroPlates (Biolog Inc.). For this, $6 \mathrm{ml}$ exponential phase cells of strain $\mathrm{B} 2-1^{\mathrm{T}}$ grown in TYEG medium were centrifuged at 6000 r.p.m. at $4{ }^{\circ} \mathrm{C}$ for $8 \mathrm{~min}$ and resuspended in $10 \mathrm{ml}$ inoculating fluid (IF). The cell-containing solution was again centrifuged and this process was repeated twice. The washed cells of strain $\mathrm{B} 2-1^{\mathrm{T}}$ were resuspended in $10 \mathrm{ml}$ IF containing 3 drops of thioglycollic acid and were inoculated into the wells of the GP2 Biolog MicroPlates as recommended by the manufac- turer. The MicroPlate was placed inside a humidified plastic sealed container and incubated at $50{ }^{\circ} \mathrm{C}$ for $5 \mathrm{~h}$. The absorbances in the wells of the MicroPlates were read and the results transformed into positive, borderline and negative scores using Biolog MicroStation system software. The results of the metabolic analysis are provided in the species description. Ambiguities exist between the substrates metabolized by strain $\mathrm{B} 2-1^{\mathrm{T}}$ and those utilized for growth in the presence of yeast extract. Such results include the positive metabolism results obtained for ribose, xylose, acetic acid and propionic acid which provided no increased growth for strain $\mathrm{B} 2-\mathrm{1}^{\mathrm{T}}$ in the presence of yeast extract. This suggests that these substrates are metabolized by strain $\mathrm{B} 2-\mathrm{1}^{\mathrm{T}}$ in a reaction where no energy generation for increased cellular growth is yielded, such as an intermediate pathway, or perhaps an additional substrate other than yeast extract is required for their utilization. Conversely, the negative metabolism result for the substrates maltose and mannitol, which provide an increased growth of strain $\mathrm{B} 2-1^{\mathrm{T}}$ in the presence of yeast extract, suggests that yeast extract is absolutely required for the metabolism of these substrates.

End products from glucose fermentation in TYEG medium were determined as previously described (Chrisotomos et al., 1996) with the exception that the oven and injector temperature were 200 and $215{ }^{\circ} \mathrm{C}$ respectively. End products from glucose fermentation were ethanol and acetate.

Electron acceptor utilization tests for sodium thiosulfate $(20 \mathrm{mM})$, sodium sulfate $(20 \mathrm{mM})$, sodium sulfite $(5 \mathrm{mM})$, elemental sulfur $(1 \%)$, sodium nitrate $(20 \mathrm{mM})$ and sodium nitrite $(5 \mathrm{mM})$ were determined in YE medium lacking the reductant $\mathrm{Na}_{2} \mathrm{~S}$. The reduction of sulfate, sulfite, elemental sulfur and thiosulfate was tested using the method of Ramamoorthy et al. (2006). Tubes were scored positive for the reduction of oxidized sulfur compounds if a black FeS precipitate formed after the addition of $0.5 \% \mathrm{Fe}\left(\mathrm{NH}_{4}\right)_{2}\left(\mathrm{SO}_{4}\right)_{2}$ to the culture tubes. The 
reduction of nitrate and nitrite to nitrogen $\left(\mathrm{N}_{2}\right)$ was determined by assessing nitrogen gas formation using a Durham tube inserted into media tubes prior to sterilization. Cultures were scored positive for the reduction of nitrate or nitrite to nitrogen if gas levels in the Durham tube were greater than those found in a control tube with no added oxidized nitrogen compounds. Reduction of nitrate to nitrite was determined using Aqua One (Australia) nitrite test kits using the protocols described by the manufacturer. Additionally, the reduction of nitrate to ammonium was subsequently tested in the same solution with the addition of $1 \mathrm{mg}$ zinc powder (Merck) and was scored positive if no colour change was observed and scored negative if a pink colour change occurred. The reduction of nitrite to ammonium was tested using Aqua One (Australia) ammonia test kits using the protocols described by the manufacturer and with uninoculated media as a control. Utilization of amorphous $\mathrm{Fe}(\mathrm{III})$ oxyhydroxide (Lovley \& Phillips, 1986) and $\mathrm{Mn}(\mathrm{IV})$ (Lovley \& Phillips, 1988) were tested at concentrations of $2 \mathrm{~g} \mathrm{l}^{-1}$ in PL medium minus ammonium $\mathrm{Fe}(\mathrm{III})$ citrate. The reduction of $\mathrm{Fe}(\mathrm{III})$ was inferred when a transformation of the reddish-brown colour of the $\mathrm{Fe}$ (III) oxide to a dark precipitate $[\mathrm{Fe}(\mathrm{II})]$ and a clearing of the media was observed. This was confirmed using the ferozine method (Sorensen, 1982). A $0.1 \mathrm{ml}$ sample was mixed with $3 \mathrm{ml}$ ferozine reagent and the absorbance at $562 \mathrm{~nm}$ was determined after $1 \mathrm{~min}$. Mn(IV) reduction was inferred by a clearing of the media and was further confirmed using the leuco crystal violet manganese oxide detection technique (Spratt et al., 1994). The concentration of $\mathrm{MnO}_{2}$ was determined by mixing a $0.2 \mathrm{ml}$ sample with $4 \mathrm{ml}$ leuco crystal violet reagent, which was diluted, and the absorbance at $562 \mathrm{~nm}$ was determined. Strain B2-1 ${ }^{\mathrm{T}}$ was able to reduce ammonium $\mathrm{Fe}(\mathrm{III})$ citrate, amorphous $\mathrm{Fe}(\mathrm{III})$ oxyhydroxide, $\mathrm{Mn}(\mathrm{IV})$ and elemental sulfur, but not sulfate, thiosulfate, sulfite, nitrate or nitrite.

Strain $\mathrm{B} 2-\mathrm{1}^{\mathrm{T}}$ was unable to grow under aerobic conditions in medium D (Brock \& Freeze, 1969) or in aerobic YE medium.

Antibiotic sensitivity was determined by adding antibiotics from filter-sterilized stock solutions to sterilized TYEG medium to final concentrations of 10 and $100 \mu \mathrm{g} \mathrm{ml}^{-1}$. Growth inhibition of each antibiotic was calculated from the final turbidity measurements of cultures that had been grown in antibiotic-free TYEG medium and growth was expressed as $\%$ inhibition. Strain $\mathrm{B} 2-\mathrm{1}^{\mathrm{T}}$ was completely inhibited (100\% inhibition) in the presence of $10 \mu \mathrm{g} \mathrm{ml}^{-1}$ ampicillin, streptomycin, tetracycline and penicillin, $100 \mu \mathrm{g}$ chloramphenicol $\mathrm{ml}^{-1}$ and $250 \mu \mathrm{g}$ sodium azide $\mathrm{ml}^{-1}$. The effect of $\mathrm{NaCl}$ on the growth of strain $\mathrm{B} 2-1^{\mathrm{T}}$ was determined by adding $\mathrm{NaCl}$ directly to Hungate tubes at concentrations of $0-5 \%(\mathrm{w} / \mathrm{v})$, the TYEG medium was dispensed and sterilized. Strain $\mathrm{B} 2-\mathrm{1}^{\mathrm{T}}$ was able to grow without $\mathrm{NaCl}$, but not at concentrations higher than $4 \%$. Reduced growth was observed at $\mathrm{NaCl}$ concentrations above $1 \%$.
To determine the $\mathrm{G}+\mathrm{C}$ content of the DNA of strain $\mathrm{B} 2-1^{\mathrm{T}}$, 21 of actively growing culture in TYEG medium was used for genomic DNA preparation. Genomic DNA was prepared using a modification of the method of Marmur (1961) in which achromopeptidase (Sigma; final concentration $0.3 \mathrm{mg} \mathrm{ml}^{-1}$ ) was used to improve cell lysis with lysozyme. The spooled DNA was dissolved in $10 \mathrm{mM}$ Tris/ $\mathrm{HCl}$ $(\mathrm{pH} 8.0)$ and the quality was assessed by agarose gel electrophoresis, ethidium bromide staining and visualization under a UVP GDAS 1200 Gel Documentation Analysis System (UVP Inc.). The $\mathrm{G}+\mathrm{C}$ content of the genomic DNA was determined by the thermal denaturation method (Marmur \& Doty, 1962) using a Cintra20 spectrophotometer (GBC Scientific Equipment) as described by Spanevello et al. (2002) and was calculated to be $48 \pm 1 \mathrm{~mol} \%$.

Inorganic $\mathrm{Fe}(\mathrm{III})$ present in $\mathrm{PL}$ medium is known to interfere with genomic DNA extraction and PCR (Kashefi et al., 2003). Thioglycollic acid pre-treatment was used to reduce $\mathrm{Fe}(\mathrm{III})$ concentrations and precipitate $\mathrm{Fe}(\mathrm{III})$ prior to genomic DNA extraction. For this, $40 \mu \mathrm{l}$ thioglycollic acid was added to $35 \mathrm{ml}$ of culture at the exponential phase in PL medium. The solution was mixed by inversion, allowed to settle for $5 \mathrm{~min}$ and the supernatant was centrifuged at 8000 r.p.m. at $4{ }^{\circ} \mathrm{C}$ for $15 \mathrm{~min}$ (Sigma $4 \mathrm{~K} 15$ ). The cell pellet was collected, resuspended in $7.5 \mathrm{ml}$ TE buffer, $10 \mu \mathrm{l}$ thioglycollic acid was added and the tube was mixed by gentle inversion. The mixture was allowed to settle, the supernatant was centrifuged again as described and the cell pellet was washed in $3.5 \mathrm{ml}$ TE buffer to remove traces of thioglycollic acid. The pellet was then resuspended in $460 \mu \mathrm{l}$ TE buffer. Genomic DNA was extracted from the pre-treated cell pellet using the modified Marmur's method described above. Aliquots of $2 \mu \mathrm{LNA}$ were used as a template for the amplification of the 16S rRNA gene (Andrews \& Patel, 1996). The sequencing of the gene was performed essentially as described previously (Andrews \& Patel, 1996). The partial sequences that were generated were assembled using BioEdit v5.0.1 (Hall, 1999) and the consensus sequence of 1627 nucleotides was corrected manually for errors. The most closely related sequences in the GenBank (version 152) and the Ribosomal Database Project II (release 9.37) identified using BLAST (Altschul et al., 1997) and the Sequence Match program (Cole et al., 2005) were extracted, aligned and manually adjusted according to the 16S rRNA secondary structure using BioEdit. Nucleotide ambiguities were omitted and evolutionary distances were calculated by using the Jukes and Cantor option (Jukes \& Cantor, 1969) in TREECON (Van de Peer et al., 1997). Phylogenetic trees were constructed from evolutionary distances using the neighbour-joining method (Saitou \& Nei, 1987). The tree topology was re-examined by the bootstrap method with 1000 replications (Felsenstein, 1985).

$16 \mathrm{~S}$ rRNA sequence analysis indicated that strain $\mathrm{B} 2-1^{\mathrm{T}}$ is related to members of the family Clostridiaceae, class Clostridia, phylum Firmicutes, and is most closely related to the uncultured bacterial clone $47 \mathrm{~mm} 70$ which was 
retrieved from a South African gold mine deep borehole (GenBank accession no. AY796047; similarity value $99.2 \%)$. Closely related uncultured organisms also include GAB clone R82, from the red mat (AY407695; similarity value $89.3 \%$ ) and $\mathrm{GAB}$ clone Y36, from the grey mat (AF407679; similarity value $89.0 \%$ ) mentioned above. The most closely related type strains of recognized species to strain $\mathrm{B} 2-1^{\mathrm{T}}$ include Geosporobacter subterraneus DSM $17957^{\mathrm{T}}$ (similarity value $89.9 \%$ ), Caminicella sporogenes DSM $14501^{\mathrm{T}}$ (similarity value $88.2 \%$ ), Clostridium caminithermale DSM $15212^{\mathrm{T}}$ (similarity value $86.8 \%$ ) and members of the genus Alkaliphilus (mean similarity $86.4 \%$ ) (Fig. 2). Although all of the species closely related to strain $\mathrm{B} 2-\mathrm{1}^{\mathrm{T}}$ originate from deep subsurface environments, few organisms shared phenotypic characteristics with strain $\mathrm{B} 2-1^{\mathrm{T}}$. The closest relative to strain $\mathrm{B} 2-1^{\mathrm{T}}, G$. subterraneus, grows optimally over a similar $\mathrm{pH}$ range to strain $\mathrm{B} 2-\mathrm{1}^{\mathrm{T}}$ and also utilizes glucose, fructose, cellobiose, Casamino acids and serine, but not ethanol, glycerol, starch, acetate, propionate, formate, lactate, threonine, glycine or cysteine, and does not reduce sulfate, sulfite, thiosulfate, nitrate or nitrite (Klouche et al., 2007). However, strain $\mathrm{B} 2-1^{\mathrm{T}}$ can be differentiated from $G$. subterraneus by its Gram-negative cell-wall ultrastructure, motility, inability to form spores, temperature optima and range, DNA $\mathrm{G}+\mathrm{C}$ content, end products from glucose fermentation, its ability to utilize mannose and mannitol, but not xylose, ribose, alanine, arginine, glutamate, glutamine or isoleucine, and its ability to reduce elemental sulfur (Table 1). Similarly, strain $\mathrm{B} 2-1^{\mathrm{T}}$ can be differentiated from Caminicella sporogenes (Alain et al., 2002) and Clostridium caminithermale (Brisbarre et al., 2003) by its smaller cell length, inability to form spores, lower optimal $\mathrm{NaCl}$ concentration for growth, greater DNA G $+\mathrm{C}$ content, the end products of glucose fermentation and by its ability to utilize cellobiose and serine. Strain $\mathrm{B} 2-\mathrm{1}^{\mathrm{T}}$ is further differentiated from Caminicella sporogenes by its ability to reduce $\mathrm{Fe}(\mathrm{III})$, but not thiosulfate, to utilize fructose and by its inability to grow at $\mathrm{pH} 5$ or below. Similarly, strain B2-1 ${ }^{\mathrm{T}}$ can be further differentiated from Clostridium caminithermale by its Gram-negative cell-wall ultrastructure, its ability to reduce sulfur and to utilize mannitol, but not ribose, glycerol, arginine, glutamate or isoleucine. Strain B2-1 ${ }^{\mathrm{T}}$ differs from members of the genus Alkaliphilus, which are mesophiles (and hence were not included in Table 1) and features a lower DNA $\mathrm{G}+\mathrm{C}$ content and is unable to ferment glucose (Cao et al., 2003; Takai et al., 2001).

Based on the phenotypic differences and the large phylogenetic distance separating strain $\mathrm{B} 2-1^{\mathrm{T}}$ from other members of the family Clostridiaceae, it is proposed that the strain should be placed in a new genus, Thermotalea gen. nov., as Thermotalea metallivorans sp. nov.

\section{Description of Thermotalea gen. nov.}

Thermotalea (Ther.mo.ta'le.a. Gr. adj. thermos hot; L. fem. n. talea a slender staff, rod; N.L. fem. n. Thermotalea a rodshaped thermophile).

Cells are strictly anaerobic, slightly curved rods. Gramreaction is negative. Cells possess peritrichous flagella. No spores are produced. $\mathrm{Fe}(\mathrm{III}), \mathrm{Mn}(\mathrm{IV})$ and elemental sulfur are reduced. 16S rRNA gene analysis indicates that the genus is a member of the family Clostridiaceae and is most closely related to the genus Geosporobacter with sequence similarities of $89.9 \%$. The type species is Thermotalea metallivorans.

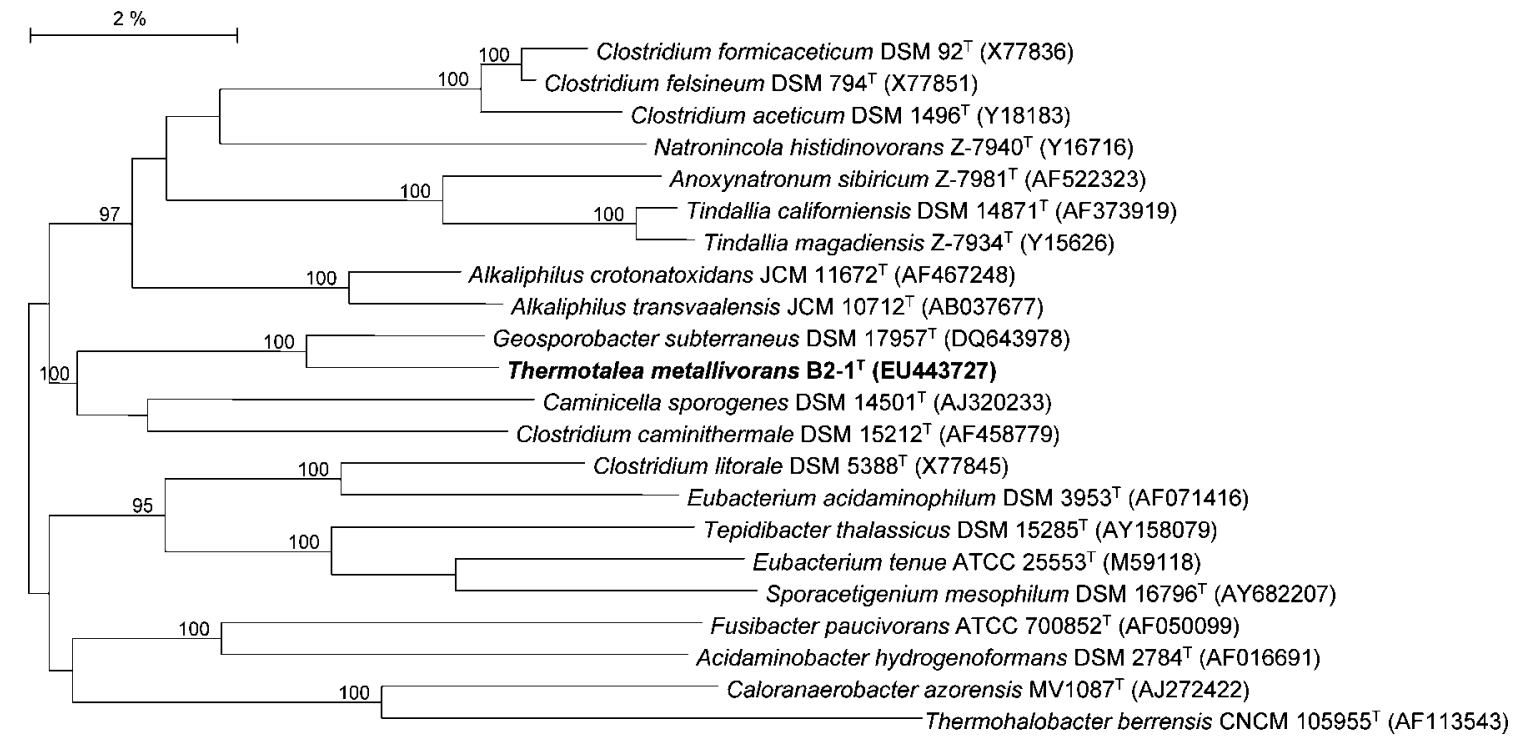

Fig. 2. A dendrogram showing the phylogenetic position of Thermotalea metallivorans sp. nov. B2-1 ${ }^{\top}$ and its closest relatives. GenBank accession numbers are given in parentheses. Bootstrap values $\geqslant 95$ are shown. Bar, 2 nucleotide changes per 100 nucleotides. 
Table 1. Selected characteristics of strain $B 2-1^{\top}$ and related members of the family Clostridiaceae

Strains: 1, B2-1 $1^{\mathrm{T}}$; 2, Geosporobacter subterraneus DSM $17957^{\mathrm{T}}$ (Klouche et al., 2007); 3, Caminicella sporogenes DSM 14501 ${ }^{\mathrm{T}}$ (Alain et al., 2002); 4, Clostridium caminithermale DSM $15212^{\mathrm{T}}$ (Brisbarre et al., 2003). +, Positive; -, negative; ND, not determined.

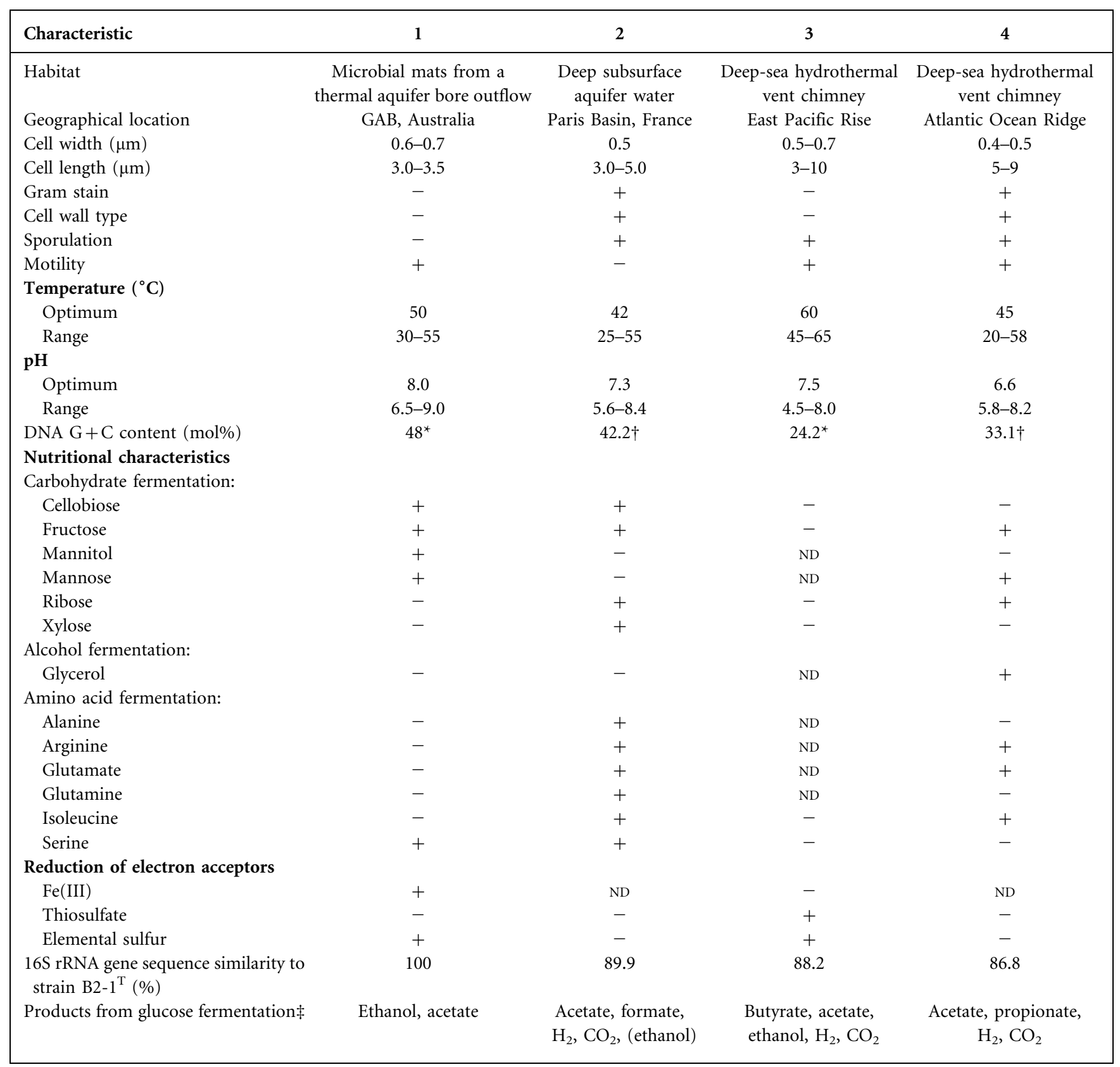

${ }^{*}$ Determined by the thermal denaturation method.

$\dagger$ Determined by HPLC.

$\ddagger$ Trace products shown in parentheses.

Description of Thermotalea metallivorans sp. nov.

Thermotalea metallivorans (me.tal.li.vo'rans. L. n. metallum metal; L. v. vorare to devour; N.L. part. adj. metallivorans metal-devouring).

Cells are 3.0-3.5 $\times 0.6-0.7 \mu \mathrm{m}$. Growth occurs between 30 and $55{ }^{\circ} \mathrm{C}$ (optimum temperature $55{ }^{\circ} \mathrm{C}$ ) and $\mathrm{pH} 6.5$ to 9 (optimum $\mathrm{pH}$ 8.0). Grows on yeast extract and tryptone as sole carbon sources. Yeast extract or tryptone is required for growth with other substrates. Grows with glucose, sucrose, maltose, fructose, arabinose, mannose, cellobiose, myo-inositol, mannitol, Casamino acids, serine, and leucine, but not with lactose, galactose, raffinose, xylose, ribose, chitin, starch, acetate, propionate, lactate, formate, 
pyruvate, ethanol, glycerol, amyl media, arginine, alanine, glycine, threonine, glutamate, isoleucine, methionine, amylopectin, casein or xylan. Metabolizes mannan, Tween 40, Tween 80, L-arabinose, D-arabitol, cellobiose, D-fructose, $\alpha$-D-glucose, myo-inositol, lactulose, D-mannose, methyl $\alpha$-D-galactoside, methyl $\beta$-D-glucoside, palatinose, ribose, sedoheptulosan, sucrose, D-tagatose, Dxylose, acetic acid, $\gamma$-hydroxybutyric acid, D-malic acid, Lmalic acid, succinic acid monomethyl ester, propionic acid, $\mathrm{N}$-acetyl-L-glutamic acid, L-asparagine, L-serine, putrescine, adenosine $5^{\prime}$-monophosphate, uridine $5^{\prime}$-monophosphate, D-fructose 6-phosphate, $\alpha$-D-glucose 1-phosphate, D-glucose 6-phosphate and DL- $\alpha$-glycerol phosphate, but not $\alpha$-cyclodextrin, $\beta$-cyclodextrin, dextrin, glycogen, inulin, $N$-acetyl-D-glucosamine, $N$-acetyl- $\beta$-D-mannosamine, amygdalin, arbutin, L-fucose, D-galactose, D-galacturonic acid, gentiobiose, D-gluconic acid, $\alpha$-D-lactose, maltose, maltotriose, D-mannitol, melezitose, melibiose, methyl $\beta$-D-galactoside, 3-methyl D-glucose, methyl $\alpha$-Dglucoside, methyl $\alpha$-D-mannoside, D-psicose, raffinose, Lrhamnose, D-salicin, D-sorbitol, stachyose, trehalose, turanose, xylitol, $\alpha$-hydroxybutyric acid, $\beta$-hydroxybutyric acid, $p$-hydroxyphenylacetic acid, $\alpha$-ketoglutaric acid, $\alpha$ ketovaleric acid, lactamide, D-lactic acid methyl ester, Llactic acid, pyruvic acid methyl ester, pyruvic acid, succinamic acid, succinic acid, L-alaninamide, D-alanine, L-alanine, L-alanyl glycine, L-glutamic acid, glycyl Lglutamic acid, L-pyroglutamic acid, 2,3-butanediol, glycerol, adenosine, $2^{\prime}$-deoxyadenosine, inosine, thymidine, uridine and thymidine $5^{\prime}$-monophosphate. End products from glucose fermentation are ethanol and acetate. Fe(III), $\mathrm{Mn}(\mathrm{IV})$ and elemental sulfur are reduced in the presence of yeast extract, but not sulfate, sulfite, thiosulfate, nitrate or nitrite. Sensitive to chloramphenicol, streptomycin, tetracycline, penicillin, ampicillin, sodium azide and to $\mathrm{NaCl}$ concentrations greater than $4 \%(\mathrm{w} / \mathrm{v})$. Phylogenetically related to Geosporobacter subterraneus DSM $17957^{\mathrm{T}}(16 \mathrm{~S}$ rRNA gene sequence similarity value $89.9 \%$ ).

The type strain, B2-1 ${ }^{\mathrm{T}}\left(=\mathrm{KCTC} 5625^{\mathrm{T}}=\mathrm{JCM} 15105^{\mathrm{T}}=\right.$ DSM $21119^{\mathrm{T}}$ ), was isolated from a microbial mat sample from the outflow of a GAB bore (New Lorne Bore) in Queensland, Australia. The G+C content of the genomic DNA of the type strain is $48 \pm 1 \mathrm{~mol} \%$.

\section{References}

Alain, K., Pignet, P., Zbinden, M., Quillevere, M., Duchiron, F., Donval, J. P., Lesongeur, F., Raguenes, G., Crassous, P. \& other authors (2002). Caminicella sporogenes gen. nov., sp. nov., a novel thermophilic spore-forming bacterium isolated from an East-Pacific Rise hydrothermal vent. Int J Syst Evol Microbiol 52, 1621-1628.

Altschul, S. F., Madden, T. L., Schäffer, A. A., Zhang, J., Zhang, Z., Miller, W. \& Lipman, D. J. (1997). Gapped BLAST and PSI-BLAST: a new generation of protein database search programs. Nucleic Acids Res 25, 3389-3402.

Andrews, K. T. \& Patel, B. K. C. (1996). Fervidobacterium gondwanense sp. nov., a new thermophilic anaerobic bacterium isolated from nonvolcanically heated geothermal waters of the Great Artesian Basin of Australia. Int J Syst Bacteriol 46, 265-269.

Brisbarre, N., Fardeau, M. L., Cueff, V., Cayol, J. L., Barbier, G., Cilia, V., Ravot, G., Thomas, P., Garcia, J. L. \& Olliver, B. (2003). Clostridium caminithermale sp. nov., a slightly halophilic and moderately thermophilic bacterium isolated from an Atlantic deepsea hydrothermal chimney. Int J Syst Evol Microbiol 53, 1043-1049.

Brock, T. D. \& Freeze, H. (1969). Thermus aquaticus gen. nov., a nonsporulating extreme thermophile. J Bacteriol 98, 289-297.

Cao, X., Liu, X. \& Dong, X. (2003). Alkaliphilus crotonatoxidans sp. nov., a strictly anaerobic, crotonate-dismutating bacterium isolated from a methanogenic environment. Int J Syst Evol Microbiol 53, 971975.

Chrisotomos, S., Patel, B. K. C., Dwivedi, P. P. \& Denman, S. E. (1996). Calormator indicus sp. nov., a new thermophilic anaerobic bacterium isolated from deep-seated nonvolcanically heated waters of an Indian artesian aquifer. Int J Syst Bacteriol 46, 497-501.

Cole, J. R., Chai, B., Farris, R. J., Wang, Q., Kulam, S. A., McGarrell, D. M., Garrity, G. M. \& Tiedje, J. M. (2005). The Ribosomal Database Project (RDP-II): sequences and tools for high-throughput rRNA analysis. Nucleic Acids Res 33, D294-D296.

Felsenstein, J. (1985). Confidence limits on phylogenies: an approach using the bootstrap. Evolution 39, 783-791.

Habermahl, M. A. (1980). The Great Artesian Basin, Australia. BMR J Aust Geol Geophys 5, 9-38.

Hall, T. A. (1999). BioEdit: a user-friendly biological sequence alignment editor and analysis program for Windows 95/98/NT. Nucleic Acids Symp Ser 41, 95-98.

Jukes, T. H. \& Cantor, C. R. (1969). Evolution of protein molecules. In Mammalian Protein Metabolism, vol. 3, pp. 21-132. Edited by H. N. Munro. New York: Academic Press.

Kanso, S. \& Patel, B. K. C. (2003). Microvirga subterranea gen. nov., sp. nov., a moderate thermophile from a deep subsurface Australian thermal aquifer. Int J Syst Evol Microbiol 53, 401-406.

Kanso, S., Greene, A. C. \& Patel, B. K. C. (2002). Bacillus subterraneus sp. nov., an iron- and manganese-reducing bacterium from a deep subsurface Australian thermal aquifer. Int J Syst Evol Microbiol 52, 869-874.

Kashefi, K., Holmes, D. E., Baross, J. A. \& Lovley, D. R. (2003). Thermophily in the Geobacteraceae: Geothermobacter ehrlichii gen. nov., sp. nov., a novel thermophilic member of the Geobacteraceae from the "Bag City" hydrothermal vent. Appl Environ Microbiol 69, 2985-2993.

Klouche, N., Fardeau, M. L., Lascourreges, J. F., Cayol, J. L., Hacine, H., Thomas, P. \& Magot, M. (2007). Geosporobacter subterraneus gen. nov., sp. nov., a spore-forming bacterium isolated from a deep subsurface aquifer. Int J Syst Evol Microbiol 57, 1757-1761.

Love, C. A., Patel, B. K. C., Nichols, P. D. \& Stackebrandt, E. (1993). Desulfotomaculum australicum, sp. nov., a thermophilic sulfatereducing bacterium isolated from the Great Artesian Basin of Australia. Syst Appl Microbiol 16, 244-251.

Lovley, D. R. (1997). Microbial Fe(III) reduction in subsurface environments. FEMS Microbiol Rev 20, 305-313.

Lovley, D. R. \& Phillips, E. J. P. (1986). Organic matter mineralization with reduction of Ferric iron in anaerobic sediments. Appl Environ Microbiol 51, 683-689.

Lovley, D. R. \& Phillips, E. J. P. (1988). Novel mode of microbial energy metabolism: organic carbon oxidation coupled to dissimilatory reduction of iron or manganese. Appl Environ Microbiol 54, 14721480. 
Marmur, J. (1961). A procedure for the isolation of deoxyribonucleic acid from microorganisms. J Mol Biol 3, 208-218.

Marmur, J. \& Doty, P. (1962). Determination of the base composition of deoxyribonucleic acid from its thermal denaturation temperature. J Mol Biol 5, 109-118.

Patel, B. K. C., Morgan, H. W. \& Daniel, R. M. (1985a). A simple and efficient method for preparing and dispensing anaerobic media. Biotechnol Lett 7, 277-278.

Patel, B. K. C., Morgan, H. W. \& Daniel, R. M. (1985b). Fervidobacterium nodosum gen. nov. and spec. nov., a new chemoorganotrophic, caldoactive, anaerobic bacterium. Arch Microbiol 141, 63-69.

Ramamoorthy, S., Sass, H., Langner, H., Schumann, P., Kroppenstedt, R. M., Spring, S., Overmann, J. \& Rosenzweig, R. F. (2006). Desulfosporosinus lacus sp. nov., a sulfate-reducing bacterium isolated from pristine freshwater lake sediments. Int J Syst Evol Microbiol 56, 2729-2736.

Redburn, A. C. \& Patel, B. K. C. (1994). Desulfovibrio longreachii sp. nov., a sulfate-reducing bacterium isolated from the Great Artesian Basin of Australia. FEMS Microbiol Lett 115, 33-38.

Saitou, N. \& Nei, M. (1987). The neighbor-joining method: a new method for reconstructing phylogenetic trees. Mol Biol Evol 4, 406425.

Sorensen, J. (1982). Reduction of ferric iron in anaerobic, marine sediment and interaction with reduction of nitrate and sulfate. Appl Environ Microbiol 43, 319-324.
Spanevello, M. D. (2001). The phylogeny of prokaryotes associated with Australia's Great Artesian Basin, pp. 198. PhD thesis, School of Biomolecular and Physical Science, Brisbane, Australia: Griffith University.

Spanevello, M. D., Yamamoto, H. \& Patel, B. K. C. (2002). Thermaerobacter subterraneus sp. nov., a novel aerobic bacterium from the Great Artesian Basin of Australia, and emendation of the genus Thermaerobacter. Int J Syst Evol Microbiol 52, 795-800.

Spratt, H. G., Jr, Siekmann, E. C. \& Hodson, R. E. (1994). Microbial manganese oxidation in saltmarsh surface sediments using a leuco crystal violet manganese oxide detection technique. Estuar Coast Shelf Sci 38, 91-112.

Takai, K., Moser, D., Onstott, T. C., Spoelstra, N., Pfiffner, S. M., Dohnalkova, A. \& Fredrickson, J. K. (2001). Alkaliphilus transvaalensis gen. nov., sp. nov., an extremely alkaliphilic bacterium isolated from a deep South African gold mine. Int J Syst Evol Microbiol 51, 1245-1256.

Van de Peer, Y., Jansen, J., De Rijk, P. \& De Wachter, P. (1997). Database on the structure of small ribosomal subunit RNA. Nucleic Acids Res 25, 111-116.

Wolin, E. A., Wolin, M. J. \& Wolfe, R. S. (1963). Formation of methane by bacterial extracts. J Biol Chem 238, 2882-2886.

Zeikus, J. G., Hegge, P. W. \& Anderson, M. A. (1979). Thermoanaerobium brockii gen. nov. and sp. nov., a new chemoorganotrophic, caldoactive, anaerobic bacterium. Arch Microbiol 122, 4148. 